Technical paper

\title{
Chemiluminescence Determination of Local Anaesthetic Mepivacaine in Human Plasma and Pharmaceuticals
}

\author{
Ali Mokhtari \\ Department of Chemistry, Faculty of Science, Golestan University, Gorgan 4913815739, I.R. Iran \\ * Corresponding author: E-mail: a.mokhtari@gu.ac.ir \\ Tel and Fax: +9817322322810
}

Received: 02-12-2015

\begin{abstract}
In this study, a new method has been developed for the simple determination of mepivacaine (carbocaine). The method is based on the enhancement effect of mepivacaine in the chemiluminescence (CL) reaction of tris $(1,10$ phenanthroline)ruthenium(II) with cerium(IV). A mechanism for the CL reaction has been proposed on the basis of UV-Vis, fluorescent and CL spectra. Under optimum conditions, the CL intensity was proportional to the concentration of the drug in solution over the range $0.45-226.25 \mu \mathrm{g} \mathrm{mL}^{-1}\left(\mathrm{R}^{2}=0.9996\right)$. The LOD was $0.34 \mu \mathrm{g} \mathrm{mL} \mathrm{L}^{-1}(\mathrm{~S} / \mathrm{N}=3)$. LOD was about 10 times lower than the therapeutic concentration of mepivacaine. The percent of relative standard deviation for determination of 11 replicates at level of $9.05 \mu \mathrm{g} \mathrm{mL}^{-1}$ and $90.50 \mu \mathrm{g} \mathrm{mL} \mathrm{L}^{-1}$ of mepivacaine were 1.8 and $3.7 \%$, respectively. The proposed method was applied successfully for the determination of mepivacaine in human plasma and injectable solutions.
\end{abstract}

Keywords: Chemiluminescence, Mepivacaine, Local Anaesthetic, Injections, Plasma, Time Resolved

\section{Introduction}

Local anaesthetics are drugs that reversibly block the conduction of impulses in the peripheral nervous system. They vary in their clinical profiles, and these differences may be related to their chemical structures. ${ }^{1}$ The amide types are widely used for various local or regional treatments. Mepivacaine (figure 1) is a local anaesthetic of the amide type. It is used for infiltration and regional anaesthesia in adults and pediatric patients. Intoxications with mepivacaine affect mainly the central nervous system (CNS) and the cardiovascular system. ${ }^{2}$ The dose administered and the pharmacokinetic profiles of the drugs determine the concentration and the sensitivity required for the analytical method. Therapeutic concentrations of mepivacaine in plasma are usually in the range of $2-5 \mu \mathrm{g} \mathrm{mL}^{-1}{ }^{3}$ It is toxic<smiles>Cc1cccc(C)c1NC(=O)[C@@H]1CCCCN1CCl</smiles>

Figure 1. Chemical structure of mepivacaine from 5 to $10 \mu \mathrm{g} \mathrm{mL} \mathrm{L}^{-1}$ and its fatal concentration is above $50 \mu \mathrm{g} \mathrm{mL}{ }^{-1}{ }^{4}$ Therefore, it is important to develop simple and sensitive methods for the determination of this drug.

Most of the proposed analytical methods for determination of mepivacaine are based on separation techniques such as liquid chromatography, ${ }^{3,5-9}$ gas chromatography ${ }^{10-14}$ and electrophoresis. ${ }^{15-16}$ Furthermore, an electrochemical method has been proposed for determination of mepivacaine. ${ }^{17}$

Chemiluminescence (CL) methods thanks to their intrinsic advantages in terms of high sensitivity, wide linear dynamic range, and simple instrumentation have become an important and valuable detection method in analytical chemistry. After the observations reported by Hercules and Lytle (1966), ${ }^{18}$ CL reactions with ruthenium(II) complexes such as tris(2,2-bipyridyl)-ruthenium(II), $\mathrm{Ru}(\mathrm{bpy})_{3}^{2+}$, and tris(1,10-phenanthroline)-ruthenium(II), $\mathrm{Ru}(\mathrm{phen})_{3}^{2+}$ have been extensively studied and exploited in a wide range of analytical applications. ${ }^{19-23}$ The $\mathrm{Ru}(\mathrm{phen})_{3}^{2+}$ has been reported to produce more intense CL and electrochemiluminescence (ECL) in aqueous solutions in comparison with $\mathrm{Ru}(\mathrm{bpy})_{3}^{2+24-27}$

Most of the separation methods such as GC and HPLC have higher sensitivity than the proposed CL met- 
hod in the determination of mepivacaine but some of them have a narrower linear dynamic range $\mathrm{f}^{7,8,10,11,13,15}$ and increased complexity. In addition, the cost of instruments are a limiting factor for routine analysis. Most important advantages of the CL method in comparison to the separation methods is the simplicity of its instrument and the speed of analysis. Maximum sampling rate in the proposed method is about 30 samples $\mathrm{h}^{-1}$. Moreover, the sensitivity of the CL method is comparable or even better than potentiometric $^{17}$ and capillary electrophoresis $(\mathrm{CE})^{16}$ methods.

In this work, it is found that the weak CL emission intensity in the $\mathrm{CL}$ system of $\mathrm{Ru}(\mathrm{phen})_{3}^{2+}-\mathrm{Ce}(\mathrm{IV})$ was greatly enhanced in the presence of mepivacaine. To the best of our knowledge, the CL determination of mepivacaine is not reported in the literature. This method has a good LOD, 10 times lower than therapeutic concentration of mepivacaine in human plasma. Moreover, the broad time profile of mepivacaine in this CL system provide the benefit of time resolved CL to reduce the effect of blank interference from pharmaceutical or plasma matrixes. The proposed method was successfully used for the quantification of mepivacaine in pharmaceuticals and human plasma samples.

\section{Experimental}

\section{1. Chemicals and Reagents}

All solutions were prepared using reagent grade chemicals and double distilled water. Mepivacaine standard solution $\left(2830.0 \mu \mathrm{g} \mathrm{mL} \mathrm{mL}^{-1}, 1.0 \times 10^{-2} \mathrm{~mol} \mathrm{~L}^{-1}\right)$ was prepared daily by dissolving $0.2830 \mathrm{~g}$ of mepivacaine hydrochloride (Sigma-Aldrich, Germany) in water in a 100.0-mL volumetric flask. Operational solutions were prepared by appropriate dilution of the stock solution when used. Standard solution of $\mathrm{Ru}(\mathrm{phen})_{3}^{2+}(0.01 \mathrm{~mol}$ $\mathrm{L}^{-1}$ ) was prepared by dissolving $0.3640 \mathrm{~g}$ of dichlorotris(1,10-phenanthroline)ruthenium(II) hydrate (SigmaAldrich, Germany) in water in a $50.0 \mathrm{~mL}$ volumetric flask. In order to prepare each one of $\mathrm{Ce}(\mathrm{IV})$ solutions with concentrations between $1.0 \times 10^{-3}$ and $2.0 \times 10^{-2} \mathrm{~mol}$ $\mathrm{L}^{-1}$, the calculated amount of ceric ammonium nitrate (Riedel-de Haën, Germany) was dissolved in appropriate volume of $\mathrm{H}_{2} \mathrm{SO}_{4}$ solution $\left(1.0 \mathrm{~mol} \mathrm{~L}^{-1}\right)$ and then, the solution was further diluted with distilled water in a 100.0$\mathrm{mL}$ volumetric flask. Final concentration of $\mathrm{H}_{2} \mathrm{SO}_{4}$ in the $\mathrm{Ce}(\mathrm{IV})$ solutions was between 0.03 and $0.20 \mathrm{~mol} \mathrm{~L}^{-1}$. Methanol was purchased from Caledon, Canada. The plasma was obtained from patients not exposed to any drug for at least $72 \mathrm{~h}$ (blank plasma) and was kindly supplied by health centre of Gorgan, Iran. Mepivacaine injections were purchased from local drugstores.

\section{2. Preparation of Plasma Samples}

Methanol was used as protein precipitant of the plasma samples. $2.0 \mathrm{~mL}$ methanol was transferred into a centrifuge tube including $1.0 \mathrm{~mL}$ plasma and the mixture was centrifuged at $5000 \mathrm{rpm}$ for $15 \mathrm{~min}$. Supernatant free of proteins was transferred into a $25.0 \mathrm{~mL}$ volumetric flask. Then, calculated volume of standard solution of mepivacaine was transferred into the flask for the purpose of spiking and then, the mixture was diluted to the mark.

\section{3. Preparation of Mepivacaine Injections}

Contents of five mepivacaine cartridges $(1.8 \mathrm{~mL}, 30$ $\mathrm{mg} \mathrm{mL}^{-1}$ ) were transferred into a small beaker. An aliquot $(1.0 \mathrm{~mL})$ of the drug was diluted serially to obtain appropriate concentration. In order to analyze the vial samples $\left(30 \mathrm{~mL}, 20 \mathrm{mg} \mathrm{mL}^{-1}\right), 1.0 \mathrm{~mL}$ of injectable solution was diluted serially to obtain appropriate concentration.

\section{4. Apparatus}

A laboratory built CL analyzer with a head on photomultiplier tube was used in this study. The light emitted by the CL reaction was detected with no wavelength discrimination. Reaction cell was a $0.50-\mathrm{cm}$ path length quartz cell. The block diagram of the instrument is shown in Figure 2.

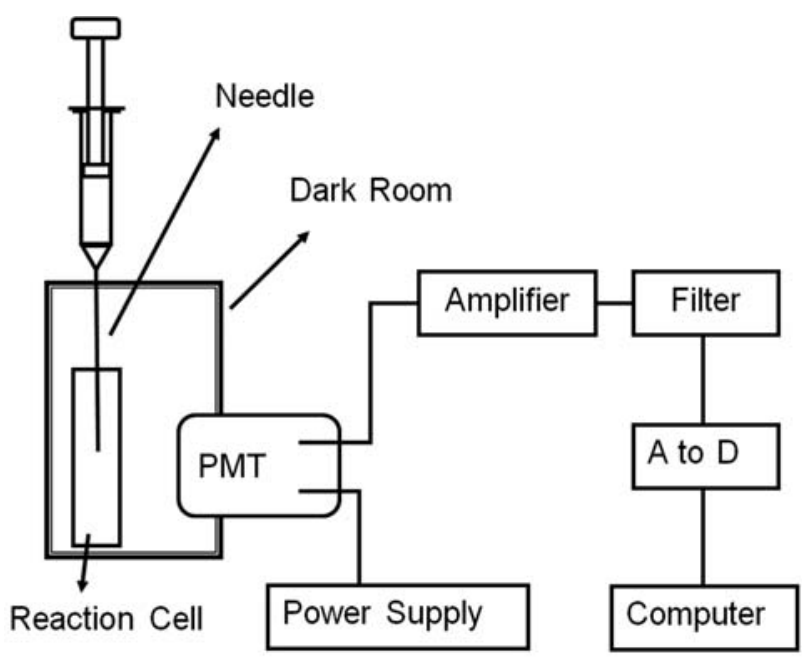

Figure 2. Schematic block diagram of the CL instrument. PMT: photomultiplier tube; A to D: Analogue-to-digital converter

\section{5. General Procedure}

Solution of mepivacaine $(400 \mu \mathrm{L})$ along with $400 \mu \mathrm{L}$ of $3.0 \times 10^{-3} \mathrm{~mol} \mathrm{~L}^{-1}$ of $\mathrm{Ru}(\text { phen })_{3}^{2+}$ were transferred into the CL cell. By placing the cell at its location in front of PMT, the program was started. After a few seconds, 200 $\mu \mathrm{L}$ of acidic $\mathrm{Ce}(\mathrm{IV})$ was injected into the cell by a microsyringe. The peak-like CL emissions were recorded in 100 ms time intervals and were automatically collected into an Excel file. 


\section{Results and Discussion}

\section{1. CL Response}

The method is based on the fact that the weak CL signal of $\mathrm{Ru}(\mathrm{phen})_{3}^{2+}$ and $\mathrm{Ce}(\mathrm{IV})$ is significantly enhanced in the presence of mepivacaine (Scheme 1).

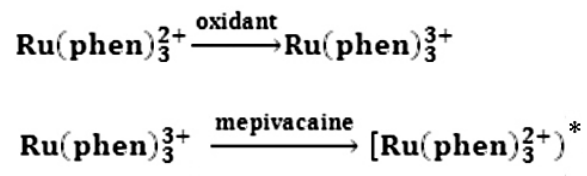

Scheme 1. General CL reactions in the system of $\mathrm{Ru}(\mathrm{phen})_{3}^{2+}-\mathrm{Ce}$ (IV)-mepivacaine

CL profiles of mepivacaine demonstrated that the $\mathrm{CL}$ reaction was slow. It took about $2 \mathrm{~s}$ to achieve the maximum peak, compared with $120-180 \mathrm{~s}$ for the signal to decline to base. In this study, height of each CL peak at second 10 after injection of Ce(IV) solution, was chosen as

a)

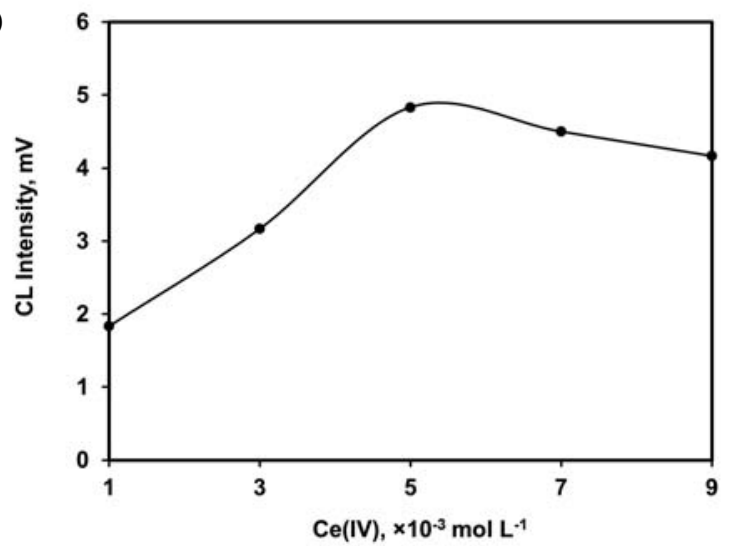

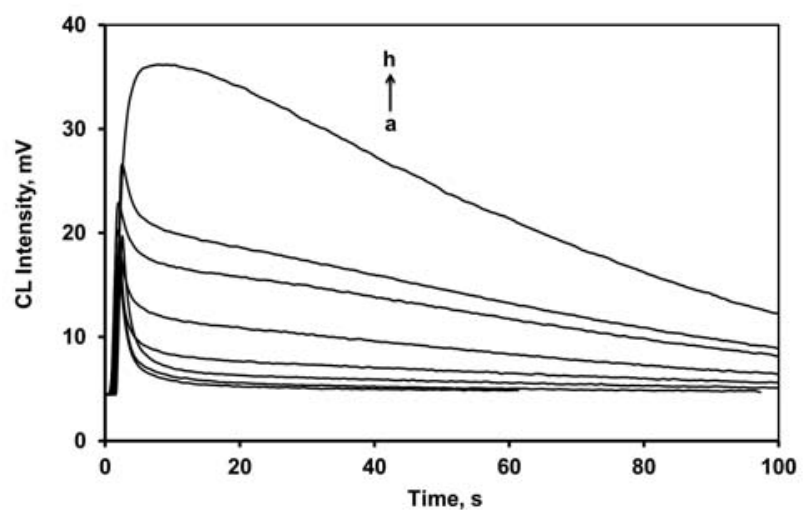

Figure 3. Typical CL profiles for different concentrations of mepivacaine including: a) blank, b) 1.13 , c) 9.05 , d) 22.63 , e) 45.25 , f) 90.50, g) 113.12 , and h) $226.25 \mu \mathrm{gL}^{-1}$.

analytical signal. Typical CL profiles of mepivacaine are shown in Figure 3.

\section{2. Optimization of Chemical Variables}

In this study, the effect of chemical variables including $\mathrm{Ru}(\text { phen })_{3}^{2+}, \mathrm{Ce}(\mathrm{IV})$, and $\mathrm{H}_{2} \mathrm{SO}_{4}$ concentrations in the

b)

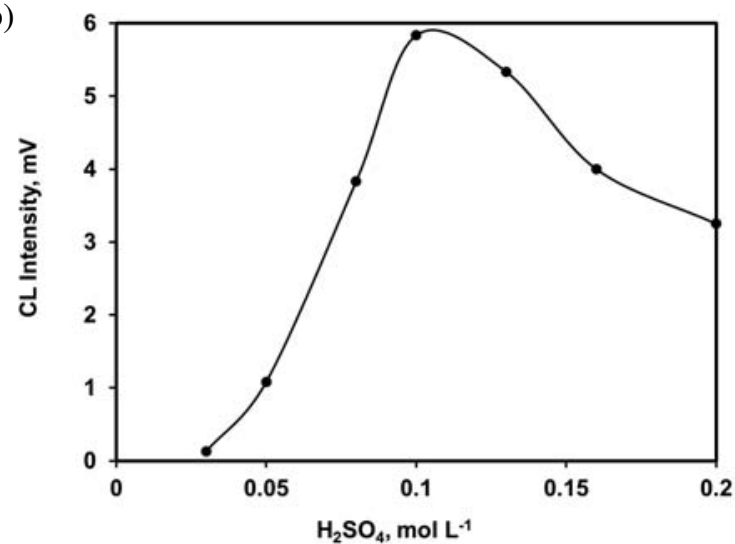

c)

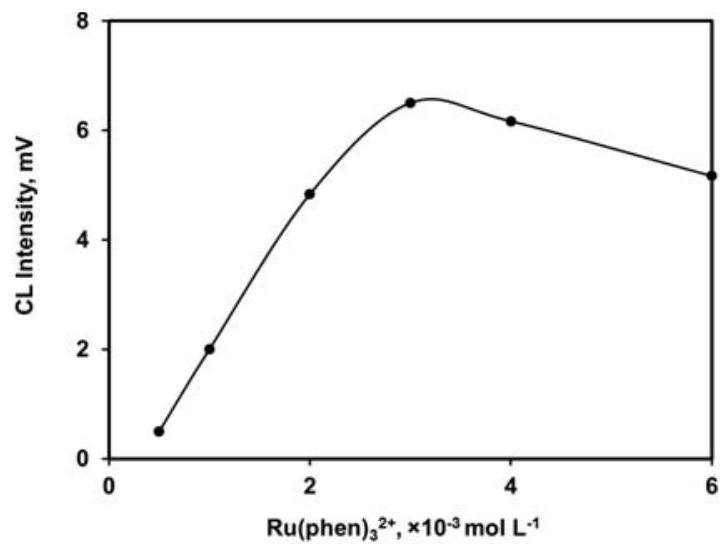

Figure 4. Optimization of chemical variables; a) $\mathrm{Ce}(\mathrm{IV}), \mathrm{b}) \mathrm{H}_{2} \mathrm{SO}_{4}$, and c) $\mathrm{Ru}(\mathrm{phen})_{3}^{2+}$. Other conditions: mepivacaine concentration was $45.25 \mu \mathrm{g}$ $\mathrm{mL}^{-1}$; a) $\mathrm{Ru}(\text { phen })_{3}^{2+}\left(2.0 \times 10^{-3} \mathrm{~mol} \mathrm{~L}^{-1}\right), \mathrm{H}_{2} \mathrm{SO}_{4}\left(0.08 \mathrm{~mol} \mathrm{~L}^{-1}\right) ;$ b) Ru(phen $\left.)_{3}^{2+}\left(2.0 \times 10^{-3} \mathrm{~mol} \mathrm{~L}^{-1}\right), \mathrm{Ce}(\mathrm{IV})\left(5 \times 10^{-3} \mathrm{~mol} \mathrm{~L}^{-1}\right) ; \mathrm{c}\right) \mathrm{Ce}(\mathrm{IV})\left(5 \times 10^{-3}\right.$ $\left.\mathrm{mol} \mathrm{L}^{-1}\right), \mathrm{H}_{2} \mathrm{SO}_{4}\left(0.10 \mathrm{~mol} \mathrm{~L}^{-1}\right)$ 
presence of mepivacaine $\left(45.25 \mu \mathrm{g} \mathrm{mL}^{-1}\right)$ were investigated. In addition, the effect of Ce(IV) solution on the sensitivity (Figure $4 \mathrm{a}$ ) in the range $(1.0$ to 9.0$) \times 10^{-3} \mathrm{~mol} \mathrm{~L}^{-1}$ and in the presence of $0.1 \mathrm{~mol} \mathrm{~L}^{-1} \mathrm{H}_{2} \mathrm{SO}_{4}$, and $2.0 \times 10^{-3}$ mol L ${ }^{-1} \mathrm{Ru}(\text { phen })_{3}{ }^{2+}$ was investigated. The maximum $\mathrm{CL}$ intensity was achieved by $5.0 \times 10^{-3} \mathrm{~mol} \mathrm{~L}^{-1} \mathrm{Ce}(\mathrm{IV})$.

Variable concentrations of $\mathrm{H}_{2} \mathrm{SO}_{4}$ solution from 0.03 to $0.20 \mathrm{~mol} \mathrm{~L}^{-1}$ were investigated in the presence of $5.0 \times$ $10^{-3} \mathrm{~mol} \mathrm{~L}^{-1} \mathrm{Ce}(\mathrm{IV})$ and $2.0 \times 10^{-3} \mathrm{~mol} \mathrm{~L}^{-1} \mathrm{Ru}(\mathrm{phen})_{3}^{2+}$. As Figure $4 \mathrm{~b}$ shows, the maximum $\mathrm{CL}$ intensity is obtained at $0.1 \mathrm{~mol} \mathrm{~L}^{-1} \mathrm{H}_{2} \mathrm{SO}_{4}$.

Under the above optimum conditions, the effect of $\mathrm{Ru}(\text { phen })_{3}^{2+}$ concentration on CL intensity is studied in the range of $(0.5-6.0) \times 10^{-3} \mathrm{~mol} \mathrm{~L}^{-1}$ of $\mathrm{Ru}(\mathrm{phen})_{3}^{2+}$. The highest response was obtained with $3.0 \times 10^{-3} \mathrm{~mol} \mathrm{~L}^{-1}$ of $\mathrm{Ru}(\text { phen })_{3}^{2+}$ (Figure 4c).

\section{3. Analytical Characteristics}

It was found that the CL response is linear in the concentration range between 0.45 and $226.25 \mu \mathrm{g} \mathrm{mL} \mathrm{m}^{-1}$. LOD was calculated at $0.34 \mu \mathrm{g} \mathrm{mL} \mathrm{m}^{-1}(\mathrm{~S} / \mathrm{N}=3)$. Reproducibility was investigated and the percent of relative standard deviations $(\mathrm{n}=11)$ for $9.05 \mu \mathrm{g} \mathrm{mL} \mathrm{L}^{-1}$ and $90.50 \mu \mathrm{g} \mathrm{m}$ $\mathrm{L}^{-1}$ of mepivacaine were 1.8 and $3.7 \%$, respectively.

\section{4. Interference Study}

The selectivity and direct application of proposed method for analyzing human plasma and injection formulations were studied by the determination of mepivacaine in presence of some interfering substances without any prior separation or isolation. In this study, some available substances or ions in our laboratory which might be present in biological fluids or pharmaceutical preparations were investigated; such as some amino acids, citric acid, $\mathrm{Fe}^{2+}$, urea, $\mathrm{Mg}^{2+}, \mathrm{HCO}_{3}{ }^{-}, \mathrm{CO}_{3}{ }^{2-}$, ascorbic acid, $\mathrm{K}^{+}, \mathrm{Na}^{+}, \mathrm{Cl}^{-}$ lactose, sucrose, glucose, fructose, saccharin, starch, $\mathrm{PO}_{4}^{3-}$, mannitol, $\mathrm{Zn}^{2+}$ and $\mathrm{SO}_{4}^{2-}$. The effect of these foreign species under optimized $\mathrm{CL}$ conditions was determined by recovering $22.63 \mu \mathrm{g} \mathrm{mL}^{-1}\left(8 \times 10^{-5} \mathrm{~mol} \mathrm{~L}^{-1}\right)$ of mepivacaine in the presence of each substance. The tolerance of each substance was taken equal to the largest amount which yields error less than $3 \sigma$ in the analytical signal from $22.63 \mu \mathrm{g} \mathrm{mL}{ }^{-1}$ of mepivacaine ( $\sigma$ is the standard deviation of response obtained from 11 repeats of the deter- mination of $22.63 \mu \mathrm{g} \mathrm{mL}^{-1}$ mepivacaine). The results are shown in Table 1.

In this CL system, protein free plasma has a sharp peak with a maximum at $0.9 \mathrm{~s}$ after injection of $\mathrm{Ce}(\mathrm{IV})$ solution and its CL response decreases rapidly to baseline after about $10 \mathrm{~s}$. Therefore, to reduce the effect of blank interferences from human plasma, the CL intensity at $10 \mathrm{~s}$ after injection of $\mathrm{Ce}(\mathrm{IV})$ solution was chosen as the analytical signal for interference and application studies.

Compounds with a tertiary amine or carboxylic acid group, and also some ions can enhance the CL intensity in the reaction between $\mathrm{Ru}(\mathrm{phen})_{3}^{2+}$ and an oxidizing agent. ${ }^{28-32}$ The CL kinetic profiles of some of investigated compounds presented in Table 1 are very or relatively sharp so that their CL intensity is little or approximately equal to zero at $10 \mathrm{~s}$ after starting CL reaction. Therefore, they have little or zero blank interferences for the determination of mepivacaine which have a broad CL time profile with a detectable response at $10 \mathrm{~s}$ after injection of $\mathrm{Ce}(\mathrm{IV})$ solution. However, some of the investigated substances such as morphine, tyrosine, and $\mathrm{I}^{-}$had an inhibition on the CL intensity and their interferences remained until $10 \mathrm{~s}$ after the start of CL reaction.

\section{5. Analysis of Human Plasma and Injectable Solutions}

The proposed method was applied for quantification of mepivacaine in injections and human plasma samples. All experiments involving human subjects were approved by Golestan University's committee, and were performed in compliance with relevant laws and institutional guidelines. Before experiments, the written consent was obtained from all human subjects. Followed procedures were in accordance to the ethical standards of the responsible committee on human experimentation (institutional and national) and with the Helsinki Declaration (1975).

The time resolved CL approach was used to reduce the effect of some blank interferences in plasma samples. It was found that a mepivacaine free plasma sample - prepared according to the procedure described in experimental section - has a sharp CL time profile with maximum value at $0.9 \mathrm{~s}$ after injection of Ce(IV) solution. CL intensity of blank plasma sample decreases rapidly to baseline after about $10 \mathrm{~s}$. Mepivacaine has a broad time profile in this CL system and its response is detectable until $120 \mathrm{~s}$

Table 1. Effect of foreign substances on determination of $22.63 \mu \mathrm{g} \mathrm{mL}^{-1}$ mepivacaine

\begin{tabular}{lc}
\hline Substance & Substance to mepivacaine $^{\mathrm{a}}$ \\
\hline urea, lactose, sucrose, glucose, fructose, saccharin, starch, valine, leucine, serine, threonine, cystine, & 500 \\
$\quad \mathrm{~K}^{+}, \mathrm{Na}^{+}, \mathrm{Cl}^{-}, \mathrm{Zn}^{2+}, \mathrm{SO}_{4}^{2-}$ & 50 \\
$\mathrm{HCO}_{3}^{-}, \mathrm{CO}_{3}^{2-}, \mathrm{PO}_{4}^{3-}$, cysteine, ascorbic acid, proline, alanine, glycine, methanol, mannitol & 10 \\
$\mathrm{Fe}^{2+}, \mathrm{Mg}^{2+}$, citric acid & 10 \\
\hline
\end{tabular}

\footnotetext{
${ }^{\text {a }}$ Molar ratio of substance to mepivacaine
} 


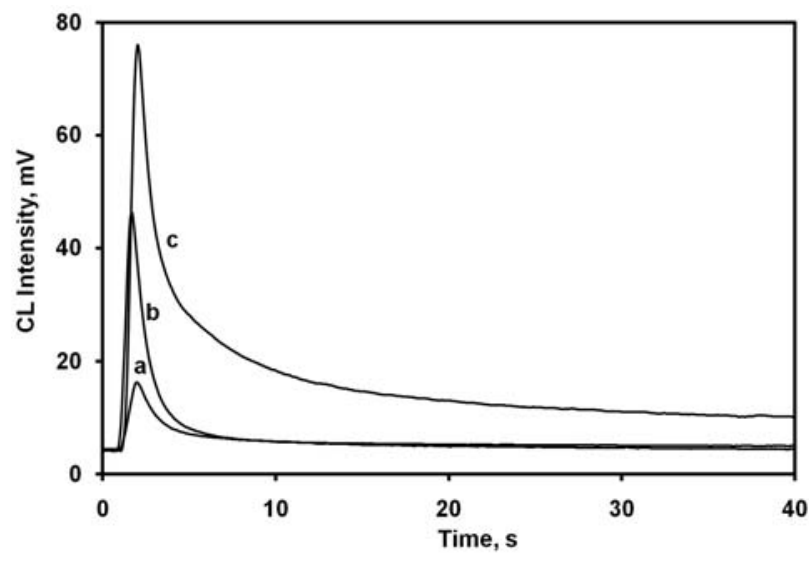

Figure 5. CL time profiles of a) blank (water), b) blank (human plasma), c) mepivacaine $\left(45.25 \mu \mathrm{g} \mathrm{m}^{-1}\right)$ in human plasma

after injection of $\mathrm{Ce}(\mathrm{IV})$ solution. Therefore, in order to reduce the effect of blank interferences in plasma samples, CL intensity at $10 \mathrm{~s}$ after injection of Ce(IV) solution was chosen as analytical signal in application studies. In this way, analytical signal could be free of blank interferences of some substances such as ascorbic acid and cysteine in human plasma. We used this strategy successfully for determination of carminic acid,$^{33}$ ketotifen, ${ }^{34}$ as- pirin,${ }^{35}$ and hydroxyzine in real samples. As can be seen in Figure 5, CL kinetic profile of plasma does not have a detectable response at $10 \mathrm{~s}$ after injection of $\mathrm{Ce}(\mathrm{IV})$ solution.

Table 2 shows the analytical recoveries from real samples.

The results of injection analysis were certified by reference method described in British Pharmacopoeia (BP) ${ }^{36}$ The accuracy and precision of the method was revealed by Student's $t$-value and variance ratio $F$-value. Statistical analysis did not detect any significant difference between the performances of the proposed and reference method. The results are summarized in Table 3.

\section{6. Possible CL Mechanism}

In this CL system, the detection chemistry generally relies upon two key steps. Firstly, chemical or electrochemical oxidation of $\mathrm{Ru}(\mathrm{phen})_{3}^{2+}$ yields $\mathrm{Ru}(\mathrm{phen})_{3}^{3+}$. Secondly, this complex is reduced by an appropriate analyte (or analyte oxidation product) to produce an electronically excited $\left[\mathrm{Ru}(\mathrm{phen})_{3}^{2+}\right]^{*}$, which can return to the base state by the emission of light. This CL matches the characteristic photoluminescence of $\mathrm{Ru}(\mathrm{phen})_{3}^{2+}$, where a short-lived triplet state is generated by the promotion of an electron from the $t_{2 g} d^{6}$ orbital in the metal to the $\pi^{*}$ antibonding orbital (a metal-ligand charge transfer; MLCT). ${ }^{37}$

Table 2. Determination of mepivacaine in real samples

\begin{tabular}{lccc}
\hline Real Sample (brand name) & Added $\left(\boldsymbol{\mu g} \mathbf{~ m L}^{-\mathbf{1}}\right)$ & Found $\left(\boldsymbol{\mu g} \mathbf{~ m L}^{\mathbf{- 1}}\right) \mathbf{c}$ & Recovery $(\boldsymbol{\%})$ \\
\hline Injection (Mepivacaine Exir) $^{\mathrm{a}}$ & 0.00 & $6.35 \pm 0.21$ & - \\
& 9.05 & $15.50 \pm 0.45$ & 101.1 \\
& 22.63 & $28.75 \pm 0.30$ & 98.9 \\
Injection (Cainamid) $^{\mathrm{b}}$ & 45.25 & $53.45 \pm 2.01$ & 104.1 \\
& 0.00 & $4.07 \pm 0.09$ & - \\
& 9.05 & $13.01 \pm 0.15$ & 98.8 \\
Plasma & 22.63 & $26.78 \pm 0.70$ & 100.4 \\
& 45.25 & $47.96 \pm 1.13$ & 97.0 \\
& 0.00 & $0.02 \pm 0.02$ & - \\
& 1.13 & $1.06 \pm 0.26$ & 92.0 \\
& 9.05 & $8.73 \pm 0.48$ & 96.2 \\
\hline
\end{tabular}

${ }^{\mathrm{a}} 1.8 \mathrm{~mL}$ cartridge (3\%, Exir Pharmaceutical Co., Iran) ${ }^{\mathrm{b}} 20 \mathrm{~mL}$ vial (2\%, Aburaihan Pharmacy Co., Iran); ${ }^{\mathrm{c}}$ Mean values of four replications

Table 3. Results of injection analysis by proposed method and their statistical comparison with reference method

\begin{tabular}{|c|c|c|c|c|c|}
\hline \multirow{2}{*}{ Injection brand name } & \multirow{2}{*}{$\begin{array}{l}\text { Nominal value } \\
\left(\mathrm{mg} \mathrm{mL}^{-1}\right)\end{array}$} & \multicolumn{2}{|c|}{ Analytical Results ${ }^{\mathrm{a}}\left(\mathrm{mg} \mathrm{mL}^{-1}\right)$} & \multirow{2}{*}{$t$-test ${ }^{\mathrm{c}}$} & \multirow{2}{*}{$F$-test $^{\text {d }}$} \\
\hline & & CL method & BP method m $^{b}$ & & \\
\hline Mepivacaine Exir & 30 & $31.75 \pm 1.05$ & $30.42 \pm 0.77$ & 2.89 & 1.86 \\
\hline Cainamid & 20 & $20.35 \pm 0.45$ & $19.72 \pm 0.97$ & 1.66 & 4.65 \\
\hline
\end{tabular}

\footnotetext{
${ }^{a}$ Mean values of four replications, ${ }^{\mathrm{b}}$ the method was based on potentiometric titration using $0.1 \mathrm{~mol} \mathrm{~L}^{-1}$ sodium hydroxide as titrant, ${ }^{\mathrm{c}}$ tabulated $t$-value at the $95 \%$ confidence level and for three degrees of freedom is 3.182, ${ }^{\mathrm{d}}$ tabulated $F$-value at the $95 \%$ confidence level and for three degrees of freedom is 9.28
} 
The color of $\mathrm{Ru}(\mathrm{phen})_{3}^{2+}$ solution changes from orange to green immediately after oxidation with Ce(IV) solution and production of $\mathrm{Ru}(\mathrm{phen})_{3}^{3+} \cdot{ }^{38,39}$ Then, the color of the mixture changes slowly from green to orange during about 3-6 min. UV-Vis spectrum of $\mathrm{Ru}(\mathrm{phen})_{3}^{2+}$ (spectrum a) and the mixture of $\mathrm{Ru}(\mathrm{phen})_{3}^{2+}-\mathrm{Ce}(\mathrm{IV})$ with one-min interval times (spectrum $b$ to $g$ ) are shown in Figure 6.

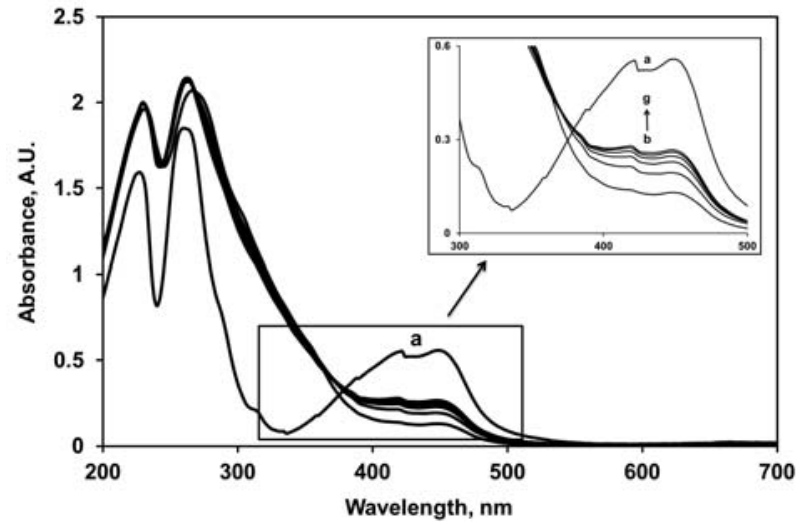

Figure 6. UV-Vis spectrum of a) $\mathrm{Ru}(\mathrm{phen})_{3}^{2+}\left(5.0 \times 10^{-5} \mathrm{~mol} \mathrm{~L}^{-1}\right)$, b to g) $2.0 \mathrm{~mL} \mathrm{Ru}(\text { phen })_{3}^{2+}\left(5.0 \times 10^{-5} \mathrm{~mol} \mathrm{~L}^{-1}\right)$ and $1.0 \mathrm{~mL} \mathrm{Ce(IV)}$ $\left(7.0 \times 10^{-4} \mathrm{~mol} \mathrm{~L}^{-1}\right.$ in $0.014 \mathrm{~mol} \mathrm{~L}^{-1}$ of $\left.\mathrm{H}_{2} \mathrm{SO}_{4}\right)$

The absorbance in the range of 400 to $500 \mathrm{~nm}$ (Figure $6 \mathrm{a})$ is related to $\mathrm{Ru}(\mathrm{phen})_{3}^{2+}$ complex. Absorbance in this region decreases immediately after mixing the $\mathrm{Ru}(\text { phen })_{3}^{2+}$ solution with $\mathrm{Ce}(\mathrm{IV})$ solution (spectrum b) and then increases slowly to its equilibrium value (spectrum $\mathrm{c}$ to g). The resulting $\mathrm{Ru}(\mathrm{phen})_{3}^{3+}$ complex produced in the oxidation reaction is a powerful oxidant and can oxidize water to protons and $\mathrm{O}_{2}$ molecules. ${ }^{40}$ Therefore, $\mathrm{Ru}(\mathrm{phen})_{3}^{3+}$ complex returns slowly to its reduced state, $\mathrm{Ru}(\mathrm{phen})_{3}^{2+}$. Reducing agents can reduce $\mathrm{Ru}(\mathrm{phen})_{3}^{3+}$ very fast. Electrons can transfer from the reducing agent to the $\pi^{*}$-orbital of phenanthroline ligands and the excited form of $\mathrm{Ru}(\mathrm{phen})_{3}^{2+}$ which is the same as $\pi^{*}$ metal-to-ligand charge transfer (MLCT) state could be produced. ${ }^{41}$ The excited electron in the $\pi^{*}$ orbital then undergoes intersystem crossing to the lowest triplet state of $\mathrm{Ru}(\mathrm{phen})_{3}^{2+}$, from where emission occurs. ${ }^{42}$

In order to approve the abovementioned mechanism, some CL pathways might be investigated for the $\mathrm{Ru}(\mathrm{phen})_{3}^{2+}-\mathrm{Ce}(\mathrm{IV})$-mepivacaine $\mathrm{CL}$ system, involving formation of excited $\mathrm{Ce}(\mathrm{III}),{ }^{43}$ oxidation products in excited states and excited form of $\mathrm{Ru}(\mathrm{phen})_{3}^{2+}$, $\left[\mathrm{Ru}(\mathrm{phen})_{3}^{2+}\right]^{*}{ }^{44}$

No detectable CL intensity was observed for the mixture of $\mathrm{Ce}(\mathrm{IV})$-mepivacaine. This suggests that oxidation products and excited $\mathrm{Ce}(\mathrm{III})$ are not the main $\mathrm{CL}$ emitters. The CL spectrum was scanned with a spectrofluorimeter (Spectrolab, model Spectro-96) in batch mode, a fast scan $\left(15000 \mathrm{~nm} \mathrm{~min}^{-1}\right)$ and with turned off excita- tion lamp. The CL spectra were acquired as shown in Figure 7 for $\mathrm{Ru}\left(\right.$ phen ${ }_{3}^{2+}-\mathrm{Ce}(\mathrm{IV})$ (spectrum a), and $\mathrm{Ru}(\mathrm{phen})_{3}^{2+}$-Ce(IV)-mepivacaine (spectrum b).

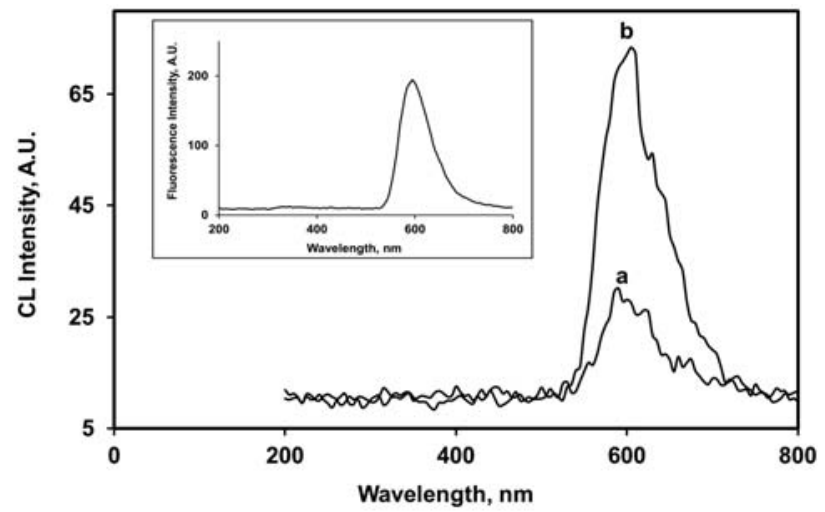

Figure 7. CL spectra of a) $\mathrm{Ru}(\text { phen })_{3}^{2+}-\mathrm{Ce}(\mathrm{IV})$ b) $\mathrm{Ru}(\mathrm{phen})_{3}^{2+}$. $\mathrm{Ce}(\mathrm{IV})-$ mepivacaine. Conditions: $200 \mu \mathrm{L}$ mepivacaine $(226.25 \mu \mathrm{g}$ $\left.\mathrm{mL}^{-1}\right), 1 \mathrm{~mL} \mathrm{Ru}(\text { phen })_{3}^{2+}\left(3.0 \times 10^{-3} \mathrm{~mol} \mathrm{~L}^{-1}\right), 0.5 \mathrm{~mL} \mathrm{Ce}(\mathrm{IV})(5.0 \times$ $10^{-3} \mathrm{~mol} \mathrm{~L}^{-1}$ in $0.1 \mathrm{~mol} \mathrm{~L}^{-1}$ of $\left.\mathrm{H}_{2} \mathrm{SO}_{4}\right)$. Inset: fluorescence emission $\left(\lambda_{\mathrm{ex}}=325 \mathrm{~nm}\right)$ of $\mathrm{Ru}(\text { phen })_{3}^{2+}$ at $595 \mathrm{~nm}$

It could be clearly indicated that the maximum emissions for both mixtures ( $a$ and $b$ ) were $\sim 595 \mathrm{~nm}$ which is the same as maximum fluorescence emission $\left(\lambda_{\mathrm{ex}}\right.$ $=325 \mathrm{~nm}$ ) of Ru(phen) $)_{3}^{2+}$ at $595 \mathrm{~nm}$ (inset in the figure 7). This indicated that the CL spectra were independent of mepivacaine and the emitter is $\mathrm{Ru}(\mathrm{phen})_{3}^{2+}$.

Mepivacaine is a tertiary amine and from previous studies, the oxidation of tertiary amines is understood to produce a short-lived radical cation. The $\alpha$-carbon is then deprotonated, yielding a strongly reducing intermediate. This reduces the $\mathrm{Ru}(\mathrm{phen})_{3}^{3+}$ (produced by oxidant) to the excited state that subsequently emits light. ${ }^{45-48}$

According to the above discussion, following mechanism is proposed for the CL reaction of mepivacaine.

$$
\begin{aligned}
& \mathrm{Ru}(\text { phen })_{3}^{2+}+\mathrm{Ce}(\mathrm{IV}) \rightarrow \mathrm{Ce}(\mathrm{III})+\mathrm{Ru}(\text { phen })_{3}^{3+} \\
& \mathrm{Hyd}+\mathrm{Ce}(\mathrm{IV}) \rightarrow \mathrm{Ce}(\mathrm{III})+\text { Mepivacaine }{ }^{+\bullet} \\
& \text { Mepivacaine }^{+\bullet} \rightarrow \text { Mepivacaine }+\mathrm{H}^{+} \\
& \mathrm{Ru}(\text { phen })_{3}^{3+}+\text { Mepivacaine }+\mathrm{H}_{2} \mathrm{O} \\
& \rightarrow\left[\mathrm{Ru}(\text { phen })_{3}^{2+}\right]^{*}+\text { Mepivacaine fragments } \\
& {\left[\mathrm{Ru}(\text { phen })_{3}^{2+}\right]^{*} \rightarrow \mathrm{Ru}(\text { phen })_{3}^{2+}+\mathrm{hv}(595 \mathrm{~nm})}
\end{aligned}
$$

\section{7. Response Characteristics}

As can be seen in Table 4, various separation techniques including gas or liquid chromatographic and electrophoresis assays have been published for determination of mepivacaine in biological samples. ${ }^{3,5-16}$ Using a sensiti- 
ve detector like mass spectrometer (MS) or pre-concentration methods such as solid phase extraction (SPE), molecularly imprinted polymers and micro-extraction, some of these methods are more sensitive than the proposed CL method. Each analytical method has its own advantages and disadvantages. The methods which use a separation technique before the detection of analytes, beside the detection of mepivacaine, can provide information about concomitants and related substances such as metabolites in the sample. However, some disadvantages could be along with them, such as time-consuming manipulations, need for superior trainings, cost of instruments, and difficulties for miniaturization.

This paper described a CL method for the determination of mepivacaine in plasma samples and injectable solutions. In comparison to the methods listed in Table 4, the proposed method is a simple and fast analytical tool for determination of mepivacaine in pharmaceuticals and human plasma prior to the use of more complex instrumental techniques. Moreover, broad time profile of mepivacaine in the proposed CL reaction has a benefit of resolved time of CL to reduce the effect of blank interference from pharmaceutical or plasma matrices.

\section{Conclusions}

The proposed method is the first reported use of a CL reaction in determination of mepivacaine. The method is based on the enhancement effect of mepivacaine on CL reaction of $\mathrm{Ru}(\mathrm{phen})_{3}^{2+}$ with acidic $\mathrm{Ce}(\mathrm{IV})$. The broad time profile of mepivacaine allowed to reduce the effect of some interfering substances such as ascorbic acid and cysteine in plasma samples. Therefore, the method is sim- ple for determination of mepivacaine in pharmaceuticals and human plasma.

\section{Acknowledgements}

The author is grateful to the campus of Golestan University for supporting this research. The author wishes to convey his special thanks to Prof. Hani Heydarzadeh for support and assistance in the work.

\section{References}

1. G. McLeod, C. McCartney, J .A. W. Wildsmith, T. Wildsmith, Principles and Practice of Regional Anaesthesia, Oxford University Press, Oxford, 2012, pp. 49-50. http://dx.doi.org/10.1093/med/9780199586691.001.0001

2. M. Froehle, N. A. Haas, G. Kirchner, D. Kececioglu, E. Sandica, Case. Rep. Pediatr. 2012, 2012, Article ID 491692.

3. M. Nieddu, G. Boatto, D. Serra, A. Soro, S. Lorenzoni, F. Lubinu, J. Forensic Sci. 2007, 52, 1223-1224. http://dx.doi.org/10.1111/j.1556-4029.2007.00526.x

4. M. Schulz, A. Schmoldt, Die Pharmazie 2003, 58, 5844758474.

5. A. Koehler, R. Oertel, W. Kirch, J. Chromatogr. A, 2005, 1088, 126-130.

http://dx.doi.org/10.1016/j.chroma.2005.03.071

6. R. Murtaza, H. L. Jackman, B. Alexander, A. Lleshi-Tali, A. P. Winnie, R. Igic, J. Pharmacol. Toxicol. Meth., 2001, 46, 131-136. http://dx.doi.org/10.1016/S1056-8719(02)00171-5

7. E. Tanaka, T. Nakamura, S. Inomata, K. Honda, J. Chromatogr. B, 2006, 834, 213-216.

http://dx.doi.org/10.1016/j.jchromb.2006.02.034

Table 4. Response characteristics of the proposed method in comparison with other methods for the determination of mepivacaine

\begin{tabular}{|c|c|c|c|c|}
\hline Method & $\begin{array}{c}\text { D.L. } \\
\left(\mu \mathrm{g} \mathrm{mL}^{-1}\right)\end{array}$ & $\begin{array}{c}\text { L.D.R. } \\
\left(\mu \mathrm{g} \mathrm{mL} \mathrm{mL}^{-1}\right)\end{array}$ & Sample & Ref. \\
\hline HPLC $^{\mathrm{a}}$ & 0.1 & $0.1-100$ & Plasma & 5 \\
\hline HPLC & NR & $0.002-1.0$ & Plasma & 6 \\
\hline HPLC & 0.1 & $0.15-2.4$ & Plasma & 7 \\
\hline HPLC & 14.5 & $1-500$ & Cerebrospinal Fluid & 3 \\
\hline LC-MS-MS $^{\mathrm{b}}$ & NR & $0.001-0.2$ & Plasma & 8 \\
\hline MIP $^{c}$-LC-MS-MS & 0.0003 & $0.0014-0.57$ & Plasma, Urine & 9 \\
\hline $\mathrm{GC}^{\mathrm{d}}$ & 0.0005 & $0.001-0.01$ & whole blood & 10 \\
\hline GC & 0.01 & $0.08-2.0$ & Plasma & 11 \\
\hline $\mathrm{SPE}^{\mathrm{e}}-\mathrm{GC}$ & 0.05 (LOQ) & NR & Plasma & 12 \\
\hline SPE-GC-MS & 0.05 & $0.5-100$ & Plasma, Urine & 13 \\
\hline$M E^{\mathrm{f}}-\mathrm{GC}-\mathrm{MS}$ & NR & $0.0014-0.57$ & Plasma & 14 \\
\hline $\mathrm{HPCE}^{\mathrm{g}}$ & 0.15 & $0.2-2.0$ & Plasma & 15 \\
\hline $\mathrm{CE}$ & 14.4 & $48.2-1000$ & Plasma & 16 \\
\hline Potentiometry & NR & $14.14-2828$ & Injections & 17 \\
\hline$C L^{h}$ & 0.34 & $0.45-226.25$ & Plasma, Injections & $\mathrm{PM}^{\mathrm{i}}$ \\
\hline
\end{tabular}

${ }^{\mathrm{a}}$ high performance liquid chromatography, ${ }^{\mathrm{b}}$ mass spectrometry, ${ }^{\mathrm{c}}$ molecularly imprinted polymer, ${ }^{\mathrm{d}}$ gas chromatography, ${ }^{\mathrm{e}}$ solid phase extraction, ${ }^{\mathrm{f}}$ microextraction, ${ }^{\mathrm{g}}$ High performance capillary electrophoresis, ${ }^{\mathrm{h}}$ chemiluminescence, ${ }^{\mathrm{i}}$ proposed method 
8. M. Siluveru, J. T. Stewart, J. Chromatogr. B, 1997, 690, 359362. http://dx.doi.org/10.1016/S0378-4347(96)00347-7

9. S. M. Daryanavard, A. Jeppsson-Dadoun, L. I. Andersson, M. Hashemi, A. Colmsjö, M. Abdel-Rehim, Biomed. Chromatogr., 2013, 27, 1481-1488. http://dx.doi.org/10.1002/bmc.2946

10. H. Hattori, S. Yamamoto, T. Yamada, O. Suzuki, J. Chromatogr. B, 1991, 564, 278-282. http://dx.doi.org/10.1016/0378-4347(91)80091-P

11. D. E. Coyle, D. D. Denson, Ther. Drug Monit., 1986, 8, 98 101. http://dx.doi.org/10.1097/00007691-198603000-00016

12. M. Baniceru, O. Croitoru, S. M. Popescu, J. Pharm. Biomed. Anal. 2004, 35, 593-598. http://dx.doi.org/10.1016/j.jpba.2004.02.012

13. T. Ohshima, T. Takayasu, J. Chromatogr. B, 1999, 726, 185194. http://dx.doi.org/10.1016/S0378-4347(98)00510-6

14. M. Abdel-Rehim, J. Chromatogr. B, 2004, 801, 317-321. http://dx.doi.org/10.1016/j.jchromb.2003.11.042

15. M. Siluveru, J. T. Stewart, J. Pharm. Biomed. Anal., 1997, 15, 1751-1756. http://dx.doi.org/10.1016/S0731-7085(96)01968-1

16. G. Morales-Cid, S. Cárdenas, B. M. Simonet, M. Valcárcel, Electrophoresis, 2009, 30,1684-1691. http://dx.doi.org/10.1002/elps.200800493

17. H. Satake, T. Miyata, S. Kaneshina, Bull. Chem. Soc. Jpn., 1991, 64, 3029-3034. http://dx.doi.org/10.1246/bcsj.64.3029

18. D. M. Hercules, F. E. Lytle, J. Am. Chem. Soc., 1966, 88, 4745-4746. http://dx.doi.org/10.1021/ja00972a052

19. A. W. Knight, TrAC Trend Anal. Chem., 1999, 18, 47-62.

20. R. D. Gerardi, N. W. Barnett, S. W. Lewis, Anal. Chim. Acta, 1999, 378, 1-41. http://dx.doi.org/10.1016/S0003-2670(98)00545-5

21. B. Rezaei, A. Mokhtari, Luminescence, 2009, 24, 183-188. http://dx.doi.org/10.1002/bio.1093

22. Z. Yan, Y. Li, J. Zheng, M. Zhou, J. Electroanal. Chem., 2014, 731, 133-138. http://dx.doi.org/10.1016/j.jelechem.2014.08.022

23. W. Qi, D. Wu, J. Zhao, Z. Liu, W. Zhang, L. Zhang, G. Xu, Anal. chem., 2013, 85, 3207-3212. http://dx.doi.org/10.1021/ac303533m

24. H.-Y. Han, Z.-K. He, Y.-E. Zeng, Fresenius J. Anal. Chem., 1999, 364, 782-785. http://dx.doi.org/10.1007/s002160051434

25. M. M. Cooke, E. H. Doeven, C. F. Hogan, J. L. Adcock, G. P. McDermott, X. A. Conlan, N. W. Barnett, F. M. Pfeffer, P. S. Fresenius J. Anal. Chem., 2009, 635, 94-101.

26. B. H. Kim, H. J. Park, J. H. Min, Y. M. Jun, S. J. Park, W.-Y. Lee, Talanta, 2004, 62, 595-602. http://dx.doi.org/10.1016/j.talanta.2003.09.001

27. S. J. Park, D. H. Kim, D. H. Kim, H. J. Park, D. N. Lee, B. H. KIM, W.-Y. LEE, Anal. Sci., 2001, 17, 93-96.

28. F. A. Aly, S. A. Al-Tamimi, A. A. Alwarthan, Talanta, 2001, 53, 885-893.

http://dx.doi.org/10.1016/S0039-9140(00)00590-7
29. F. E. O. Suliman, M. M. Al-Hinai, S. M. Al-Kindy, S. B. Salama, Luminescence, 2009, 24, 2-9. http://dx.doi.org/10.1002/bio.1054

30. M. Zorzi, P. Pastore, F. Magno, Anal. Chem., 2000, 72, 4934-4939. http://dx.doi.org/10.1021/ac991222m

31. A. Mokhtari, M. Keyvanfard, I. Emami, RSC Adv., 2015, 5, 29214-29221.

32. B. Rezaei, A. Mokhtari, Spectrochim. Acta A, 2007, 66, 359363. http://dx.doi.org/10.1016/j.saa.2006.03.005

33. A. Mokhtari, M. Keyvanfard, I. Emami, Food Anal. Meth., 2015, 8, 2457-2464. http://dx.doi.org/10.1007/s12161-014-0052-z

34. A. Mokhtari, M. Ghazaeian, M. Maghsoudi, M. Keyvanfard, I. Emami, Luminescence, 2015, 30, 1094-1100. http://dx.doi.org/10.1002/bio.2864

35. A. Mokhtari, M. Keyvanfard, I. Emami, N. Jafari Delouei, H. Fathipour Pishkhani, A. Ebrahimi, H. Karimian, J. Brazil. Chem. Soc., 2015, http://dx.doi.org/10.5935/0103-5053.20150288.

36. Gaur R, Azizi M, Gan J, Hansal P, Harper K, Mannan R, Panchal A, Patel K, Patel M, Patel N, Rana J and Rogowska A 2009 in British Pharmacopoeia Volume I \& II. (London: British Pharmacopoeia Commission).

37. G. P. McDermott, E. M. Zammit, E. K. Bowen, M. M. Cooke, J. L. Adcock, X. A. Conlan, F. M. Pfeffer, N. W. Barnett, G. A. Dyson, P. S. Francis, Anal. Chim. Acta, 2009, 634, 222-227. http://dx.doi.org/10.1016/j.aca.2008.12.030

38. R. Yoshida, T. Ueki, NPG Asia Mater., 2014, 6, e107. http://dx.doi.org/10.1038/am.2014.32

39. D. Hong, J. Jung, J. Park, Y. Yamada, T. Suenobu, Y.-M. Lee, W. Nam, S. Fukuzumi, Energy Environ. Sci., 2012, 5, 7606-7616. http://dx.doi.org/10.1039/c2ee21185h

40. M. Hara, C. C. Waraksa, J. T. Lean, B. A. Lewis, T. E. Mallouk, J. Phys. Chem. A, 2000, 104, 5275-5280. http://dx.doi.org/10.1021/jp000321x

41. W. L. Wallace, A. J. Bard, J. Phys. Chem., 1979, 83, 13501357. http://dx.doi.org/10.1021/j100473a022

42. E. Bolton, M. M. Richter, J. Chem. Educ., 2001, 78, 47-51. http://dx.doi.org/10.1021/ed078p47

43. A. Campiglio, Analyst, 1998, 123, 1571-1574. http://dx.doi.org/10.1039/a802013b

44. N. E. Tokel-Takvoryan, R. E. Hemingway, A. J. Bard, J. Am. Chem. Soc., 1973, 95, 6582-6589. http://dx.doi.org/10.1021/ja00801a011

45. F. A. Aly, S. A. Al-Tamimi, A. A. Alwarthan, Talanta, 2001, 53, 885-893. http://dx.doi.org/10.1016/S0039-9140(00)00590-7

46. C. Thongpoon, B. Liawruangrath, S. Liawruangrath, R.A. Wheatley, A. Townshend, Anal. Chim. Acta, 2005, 553, 123133. http://dx.doi.org/10.1016/j.aca.2005.07.056

47. G. Greenway, S.L. Dolman, Analyst, 1999, 124, 759-762. http://dx.doi.org/10.1039/a901058k

48. X. Chen, C. Yi, M. Li, X. Lu, Z. Li, P. Li, X. Wang, Anal. Chim. Acta, 2002, 466, 79-86. http://dx.doi.org/10.1016/S0003-2670(02)00546-9 


\section{Povzetek}

V tej študiji smo razvili novo metodo za preprosto določanje mepivakaina (karbokaina). Metoda temelji na dejstvu, da mepivakain ojači kemiluminescenco (CL) pri reakciji med tris(1,10 fenantrolin)rutenijevimi(II) ioni in cerijevimi(IV) ioni. Mehanizem CL reakcije predlagamo na osnovi UV-Vis, fluorescenčnih in CL spektrov. Pri optimalnih pogojih je intenziteta CL sorazmerna koncentraciji učinkovine v raztopini v območju $0,45-226,25 \mu \mathrm{g} \mathrm{mL} \mathrm{m}^{-1}\left(\mathrm{R}^{2}=0,9996\right)$. LOD je $0,34 \mu \mathrm{g} \mathrm{mL} \mathrm{L}^{-1}(\mathrm{~S} / \mathrm{N}=3)$. LOD je okrog 10-krat nižji od terapevtske koncentracije mepivakaina. Relativni standardni od-

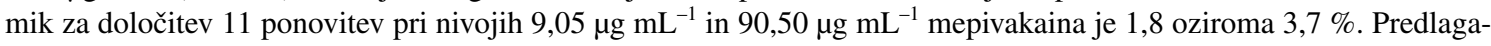
no metodo smo uspešno uporabili za določitev mepivakaina $v$ humani plazmi in v raztopinah za injekcije. 